\begin{tabular}{l|l|l|l} 
Cose Reports in & $\begin{array}{l}\text { Case Rep Neurol 2010;2:1-4 } \\
\text { D0I: 10.1159/000264609 }\end{array}$ & Published online: January 15, 2010 & $\begin{array}{l}\text { ○ 2010 S. Karger AG, Basel } \\
\text { ISSN 1662-680X } \\
\text { www.karger.com/crn }\end{array}$ \\
\hline
\end{tabular}

\title{
Topiramate Treatment of Essential Tremor in a Patient with Cognitive Deficits
}

\author{
F. Leblhuber K. Steiner \\ Department of Gerontology, o.ö. Landesnervenklinik Linz, Linz, Austria
}

\section{Key Words}

Essential tremor $\cdot$ Topiramate $\cdot$ Cognitive decline $\cdot$ MMSE

\begin{abstract}
This case report demonstrates a satisfying response to topiramate in a 79-year-old patient with disabling essential tremor in whom propranolol as well as primidone had to be discontinued due to severe side effects. After 28 months of topiramate treatment, a clear decline in Mini Mental State Examination (MMSE) could be observed, stressing the use of care in prescribing topiramate in elderly patients.
\end{abstract}

\section{Introduction}

Essential tremor is a common movement disorder, especially in later life [1]. It usually affects both upper extremities, furthermore head, lower limbs, neck and voice [2].

Propanolol and primidone are first-line treatments, improving tremor in up to two thirds of cases [3]. Propanolol and primidone cause side effects, especially in the elderly, and interact often with drugs usually used in older people [4]. Topiramate was referred being effective in treating essential tremor in case studies [5] as well as in double-blind placebocontrolled studies [2].

\section{Case Report}

A 79-year-old right-handed man with a history of tremor with insidious onset and gradual deterioration over years presented with severe postural tremor of both arms worsening with action. In his history, there was no condition or drug causing enhanced physiological tremor, there were no cerebellar signs or symptoms, no hyperthyroidism, no alcoholism, no peripheral neuropathy, and no anxiety state according to the criteria of definite essential tremor (ET) of Koller and Busenbark [6].

In his medical history was hypertension and diabetes, both for a short period of time and of rather little clinical significance so far. Brain CT scan showed diffuse cerebral atrophy and vascular leukoaraiosis. The Mini Mental State Examination (MMSE) was 23 of 28 points at the first clinical

Univ. Doz. Prim. Dr. Friedrich Leblhuber
Landesnervenklinik Wagner-Jauregg, Wagner-Jauregg Weg 15 AT-4020 Linz (Austria)

Tel. +43 7326921 33500, Fax +43 7326921 23534, E-Mail friedrich.leblhuber@gespag.at 


\begin{tabular}{l|l|l|l} 
Cose Reports in & $\begin{array}{l}\text { Case Rep Neurol 2010;2:1-4 } \\
\text { Dol: } 10.1159 / 000264609\end{array}$ & Published online: January 15, 2010 & $\begin{array}{l}\text { @ 2010 S. Karger AG, Basel } \\
\text { ISSN 1662-680X } \\
\text { www.karger.com/crn }\end{array}$ \\
\hline
\end{tabular}

examination (writing a sentence and drawing 2 pentagons was not possible), indicating mild primary degenerative dementia. There was no familial history of ET.

Medication was started years before by a general practitioner with levodopa, bupranolol and diazepam. Under this medication, tremor gradually and finally rapidly worsened, so that the patient was not able to drink, eat or dress without help, nor was he able to write or draw anymore.

At our department, treatment was changed to propanolol $120 \mathrm{mg} /$ day with no effect (see fig. 1a). Furthermore, propanolol had to be discontinued due to vertigo and a remarkable decrease in heart frequency. Medication was changed to primidone $250 \mathrm{mg} /$ day (blood level $20 \mathrm{mmol} / \mathrm{l}$ ), but primidone had to be discontinued, too, because of similar side effects. Writing was still not possible (see fig. 1b). Therefore, medication with topiramate, first with a daily dosage of $25 \mathrm{mg} / \mathrm{day}$, was started and tolerated well, so the dosage could be increased gradually to $100 \mathrm{mg} /$ day (blood level $4.5 \mu \mathrm{g} / \mathrm{ml}$ ) within two weeks. ET disappeared almost completely and no functional disabilities in daily living were reported anymore. Writing and drawing was possible again (see fig. 1c, d).

Under medication of topiramate, MMSE gradually decreased over 28 months from 23 of 28 points to finally 13 of 30 possible points, and the patient's spouse reported clear cognitive decline in our patient. Concomitant medication with potential pro-dementing effect like diazepam had already been discontinued, memantine was established from the beginning of our treatment. There was still a continuing ameliorating effect of topiramate on ET, making simple activities of daily living (eating, dressing, etc.) still possible, which overweighed the harm of cognitive function. Cognitive dysfunction was described earlier in patients with specific vulnerability under topiramate treatment [7].

\section{Conclusion}

In this case of a 79-year-old patient with ET, after unresponsiveness to propanolol and primidone, treatment with topiramate was found to be very effective. During topiramate treatment, the MMSE dropped 10 points, more than $20 \%$ per year, compared to the treatment before topiramate. The rate of decline on MMSE during the course of dementia is reported to be highly variable [8] and could be due to the preexisting dementia itself as well as due to the concomitant diseases diabetes and hypertension in our case, although no recent lacunas were found on brain CT controls.

In summary, this case study demonstrates an additional opportunity to treat ET in elderly patients with dementia, but prescription should be considered very carefully with frequently performed titration to find out the lowest effective dosage [5], and monitoring of the mental status should be performed regularly under topiramate treatment. 
Cose Reports in

Case Rep Neurol 2010;2:1-4

Published online: January 15, 2010

() 2010 S. Karger AG, Basel

ISSN 1662-680X

3

Fig. 1. Patient's writing and drawing under medication of bupranolol $60 \mathrm{mg}$ and diazepam $2.5 \mathrm{mg}(\mathbf{a})$, primidone $250 \mathrm{mg}$ (b) and topiramate $100 \mathrm{mg}(\mathbf{c}, \mathbf{d})$.

a

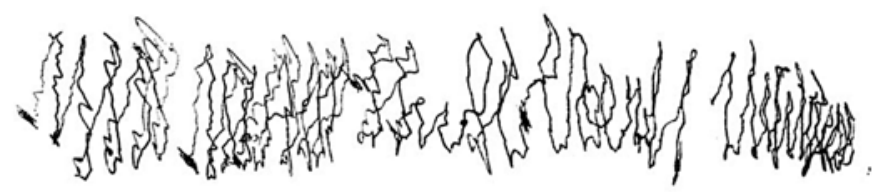

b
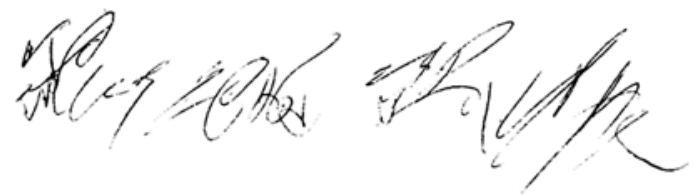

c

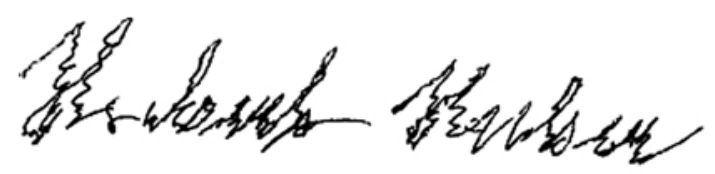

d

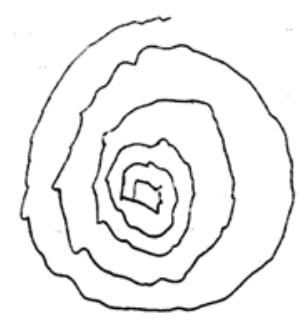

뜬 


\section{References}

1 Louis ED, Ottmann R, Hauser WA: How common is the most common adult movement disorder? Estimates of the prevalence of essential tremor throughout the world. Mov Disord 1998;13:5-10.

2 Ondo WG, Jankovic J, Connor GS, Pahwa R, et al: Topiramate in essential tremor. Neurology 2006;66:672-677.

-3 Koller WC, Vetere-Overfield B: Acute and chronic effects of propanolol and primidone in essential tremor. Neurology 1989;39:1587-1588.

4 Hansten PD, Horn JR: St. Louis: Facts and comparisons; in Wickersham RM, O’Dell JA (eds): Managing Clinically Important Drug Interactions. Amsterdam, Wolters Kluwer, 2004.

-5 Gatto EN, Ruca MC, Raina G, Micheli F: Low doses of topiramate are effective in essential tremor, a report of three cases. Clin Neuropharmacol 2003;26:294-296.

6 Koller WC, Busenbark Kl: Essential tremor; in Watts RL, Koller WC (eds): Movement Disorders. McGraw-Hill Companies, 1996.

7 Mula M, Trimble MR, Thompson P, Saner JWAS: Topiramate and word finding difficulties in patients with epilepsy. Neurology 2003;60:1104-1107.

8 Hodges JR, Erzinclioglu S, Patterson K: Evolution of cognitive deficits and conversion to dementia in patients with mild cognitive impairment: a very-longterm follow-up study. Dement Geriatr Cogn Disord 2006;21:380-391. 